\title{
A lexikális jelentésviszonyok élményközpontú tanítása multimediális szövegekkel
}

\author{
Szerdi llona \\ Selye János Egyetem, Magyar Nyelv és Irodalom Doktori Iskola
}

\begin{abstract}
Összefoglaló
Tanulmányomban a lexikális jelentésviszonyok tanításának újabb lehetőségeit mutatom be az interneten - elsősorban a Facebookon - megjelent szövegeken és kép-szöveg együtteseken keresztül. A hangalak és a jelentés kapcsolatát - főként a poliszémiát és a homonímiát - négy csoporton belül tárgyalom: 1 . lexikális jelentésviszonyok a kép-szöveg kapcsolatokban; 2. az ékezethiányos írásmód eredményezte homonímia; 3. kvázi-poliszémikus szimbólumjáték; 4. homonimitás az akronimákban. Ezt követően javaslatot teszek a hangalak és a jelentés kapcsolatát tárgyaló, a szlovákiai magyar anyanyelvoktatásban használt tankönyvek vonatkozó fejezeteinek elméleti és gyakorlati kiegészítésére is.
\end{abstract}

Kulcsszavak: lexikális (lexikológiai) jelentésviszonyok; poliszémia; homonímia; oktatás; multimediális szövegek; kép-szöveg együttesek; internetes mémek

\section{Bevezetés}

A Z generáció diákjai komfortosabban mozognak a képgazdag környezetben, mint az írott szövegekben, hatékonyabban tanulnak felfedezések útján, mint szóbeli magyarázattal, játék- és fantáziaorientáltak, figyelmüket az őket megelőző generációkhoz képest gyorsabban tudják egyik dologról a másikra irányítani, a kommunikációban gyorsabban reagálnak a partner jelzéseire, és ezt a másik féltől is elvárják (vö. Prensky 2001; Manuel 2002; Jakab 2011; Pais 2013; Szekszárdi 2015).

Az oktatási folyamatban is érdemes felhasználni a képiséget, a fantáziát, a játékosságot és a humort (vö. Grétsy 2000; Séra 2008; Patakfalvi 2009; Hegedüs 2010). Tanulmányomban mindezeket eszközként alkalmazom a diákok anyanyelvi ismeretek iránti motivációjának növelésére (vö. Schirm 2013; Fegyverneki 2014). Schirm Anita A humor szerepe a nyelvészet oktatásában c. tanulmányában (2013) olyan kép-szöveg kapcsolatokat, dalszövegeket és óriásplakátok feliratait sorakoztatja fel, amelyek humoros jellegüknél fogva a stilisztika oktatását, tanulását könnyíthetik meg. Hasonlóképpen teszek én is javaslatot a lexikális jelentésviszonyok tanítására, kihasználva a mémek és egyéb kép-szöveg együttesek humorforrását. Kutatásom létjogosultságát Lőrincz Gábor tanulmánya is alátámasztja (Lőrincz 2011), amelyben a szerző a szlovákiai magyar általános iskolások jelentéstani ismereteinek hiányosságaira hívja fel a figyelmet. 
A hangalak és a jelentés kapcsolatát - főként a poliszémiát és a homonímiát négy csoporton belül tárgyalom: 1. lexikális jelentésviszonyok a kép-szöveg kapcsolatokban; 2. az ékezethiányos írásmód eredményezte homonímia; 3 . kvázipoliszémikus szimbólumjáték (saját fogalom; vö. grafikus játék a szavakkal, Renner 2015: 127-128); 4. homonimitás az akronimákban.

\section{Anyag és módszer}

Tanulmányomban a lexikális jelentésviszonyok tanításának újabb lehetőségeit az interneten - elsősorban a Facebookon - megjelent szövegeken, kép-szöveg együtteseken keresztül mutatom be. A multimediális szövegekben megragadható jelentésviszonyok hátterében a grice-i maximasértéseknek, a forgatókönyvváltásnak (lásd Raskin és Attardo forgatókönyv-elméletét: Raskin 1984; Attardo 1994; vö. Jellinek 2015; Nemesi 2015) és a félreérthetőségnek köszönhető humoros hatás áll.

Domonkosi Ágnes egyik tanulmányában (Domonkosi 2005) az internetes nyelvhasználat empirikus kutatásának három lehetőségét - kérdőívezés, megfigyelés, korpuszelemzés - ismerteti. A gyűjtést ennek alapján külső megfigyeléssel végeztem, az összegyűjtött anyagot pedig a lexikális jelentésviszonyok szempontjából elemeztem. A megfigyelés esetünkben azért alkalmas vizsgálati módszerként, mert a szövegeket digitális környezetükben figyelhetjük meg, így hatékonyan elemezhető többek között a játékosság, a többértelműségre való törekvés, a félreérthetőség és a félreértés (vö. Domonkosi 2005: 153). Az elemzés során több mint 70 kép-szöveg együttessel dolgoztam, a korpuszomat azonban továbbra is folyamatosan bővítem.

\section{Poliszémia és homonímia a multimediális szövegekben}

Korunkban a digitális technológia, az internet térnyerése alatt „(r)észben visszatérünk az ősi és azóta sem elfelejtett kommunikációs formánkhoz, az élőbeszédhez, amelyben a hangok mellett a jelenlétnek, jelenidejűségnek, valamint a látványnak (képeknek) volt nagy szerepük. Ez valamiféle visszatalálást jelent a sokáig mellözött vizualitáshoz (képszerüséghez)" (Balázs 2005: 28).

Petőfi S. János a verbális médium, a képi kommunikáció, a zene, a tánc stb. médiumának egy adott kommunikációs szituációban funkcionálisan adekvát üzenettel való összekapcsolódását multimediális kommunikátumnak nevezi. A multimediális szöveget - mint multimediális kommunikátumot - a nyelvi elemek (verbális médium) dominanciája vagy egyenrangúsága jellemzi (Petőfi 1996: 88). Szikszainé Nagy Irma a verbális médiumhoz kapcsolódó elem szerepét emeli ki a meghatározásában: „az extralingvisztikai eszközök egyenrangúak vagy meghatározók ebben a heterogén jelegyüttesben [ti. a nyelvi jelek és a zenei vagy képi jelek együttesében - szerk. megj.]" (Szikszainé 1999: 125). Tanulmányomban minden olyan, a digitális kommunikációban megjelenő szövegre multimediális szövegként tekintek, amely valamilyen más, nem verbális médiummal kapcsolódik, függetlenül az egyes médiumok dominanciájának mértékétől. A multimediális szövegek közül jelen kutatásomban csupán a kép és szöveg kapcsolatát elemzem. Ezek egymáshoz való viszonyát bár többféleképpen is meghatározhatjuk (vö. Szikszainé 1999: 127-128; Nyíri 2011; Veszelszki 2012), a következőkben egy egyszerű hármas felosztást követek: 
1. a szöveg elsőrendű a képpel szemben (a kép csak illusztratív jellegű);

2. a kép az elsőrendű a szöveggel szemben (a kép a szöveg nélkül is értelmezhető; pl. festmény);

3. a kép és a szöveg kölcsönhatásban van (pl. internetes mémek).

Jelen tanulmányomban a poliszém és a homonim jelentésviszonyok vizsgálatára helyezem a hangsúlyt. Míg az előbbit egy adott hang-, illetve szóalak jelentéseinek szemantikailag motivált kapcsolata, addig az utóbbit ennek hiánya jellemzi. A két kategória közötti határvonal azonban nem egyértelmű: a jelentésviszony megállapítása diakrón (etimológia) és szinkrón (a beszélő tudata, nyelvérzék) szempontú megközelítése is lehetséges (vö. Károly 1970: 85; Kiefer 2007: 121-127). Korpuszomban a két jelentésviszonyt szinkronikus alapon különítem el egymástól. A vizsgált kép-szöveg kapcsolatok poliszemantikus szavainak jelentései közötti viszony többnyire metaforikus (vö. Károly 1970: 369). A szavak, szókapcsolatok poliszém jellegét erősíti a kontextus - a szöveg és a képi elem - is (a poliszémia és a kontextus kapcsolatáról I. Kiefer 2007: 129-138; Cseresnyési 2009). Az, hogy melyik (kontextuális) jelentés érvényesül, az olvasat, illetve az olvasás fázisának a függvénye. A homonímiát mutató multimediális szövegekben az azonos alakúság több formája is megjelenik: a szótári homonímia, a homofónia, a homográfia, a grammatikai és a vegyes szerkezetű homonímia (a homonímia kategorizálásáról vö. Károly 1970: 80-81; Pethő 2006: 66-70; Lőrincz 2015: 61-63).

$\mathrm{Az}$ alábbiakban a fentebb (I. Bevezetés) megnevezett négy csoporton belül szemléltetem a multimediális szövegekben megjelenő jelentésviszonyokat.

\subsection{Lexikális jelentésviszonyok a kép-szöveg kapcsolatokban}

Az első - kissé általánosabb - kategóriában olyan kép-szöveg kapcsolatokat sorakoztatok fel, amelyekben a szöveg egy-egy kifejezésének másodlagos vagy harmadlagos jelentésére a képi elem erősít rá. Egynéhány esetben azonban a kép mint háttérelem, esztétikai komponens csupán az elsődleges jelentést illusztrálja.

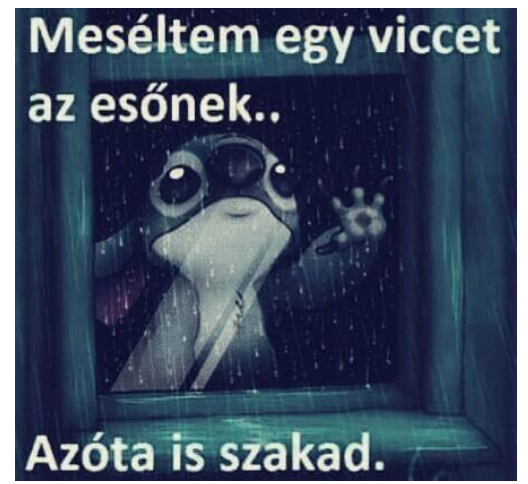

1. ábra ${ }^{1}$

${ }^{1}$ Az ábra forrása: Hungaro-Mém Hungarizált Mémek Facebook-oldal: https://goo.gl/Nuq6eV [2017. március 27.] 
A kép és a szöveg egymáshoz való viszonyát tekintve az 1. ábrán a kép illusztratív jellegü, a szöveg az elsődleges. A Meséltem egy viccet az esónek... Azóta is szakad. képfelirat csattanója a szakad szó két, egymással poliszemantikus viszonyban álló jelentéséből fakad: 1) ömlik az eső, nagyon esik; 2) megszakad a nevetéstöl, hangosan (nagyon) nevet. A szöveg humoros hatása Raskin és Attardo forgatókönyv-elméletével magyarázható (vö. Jellinek 2015; Nemesi 2015). A két tagmondat között forgatókönyvváltást figyelhetünk meg: első olvasatra a befogadóban az ESIK forgatókönyve aktiválódik, az újraolvasást követően pedig azt a NEVETÉS-forgatókönyv váltja fel.

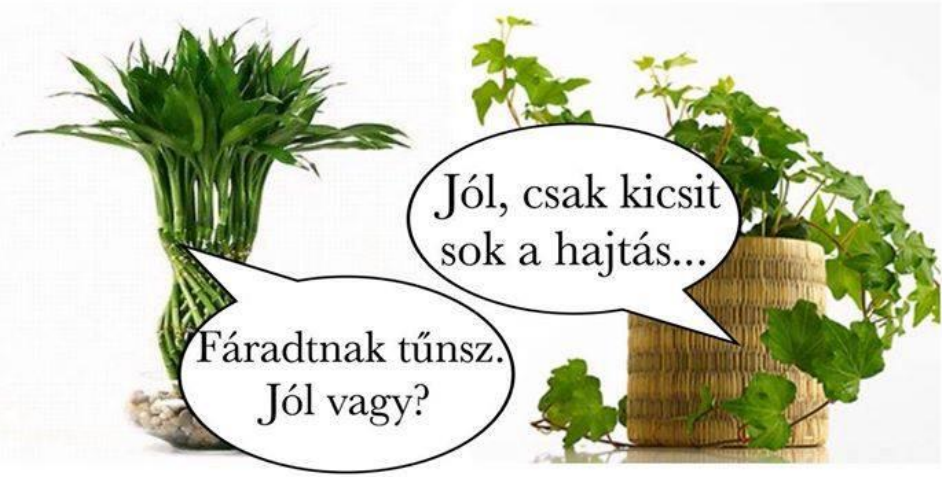

2. ábra ${ }^{2}$

A 2. ábrán a kép és a szöveg kölcsönhatásban van egymással. A Fáradtnak tünsz. Jól vagy? kérdésre adott válasz hajtás szavában a rohanás, hajsza, sok a tennivaló értelmezés érvényesül. A képi inger bevonását követően azonban a lexéma egy újabb jelentése kerül előtérbe: a növény hajtása. A másodlagos jelentést a képi elem értelmezésbe való bevitele hozza létre. A két jelentés között homonimikus viszony (szótári homonímia) figyelhető meg.

A 3. ábrán szintén egy párbeszédet olvashatunk:

- Hogy ment a mai vadászat?

- Elejtettem egy nyulat.

- Szuper! Na és hol van?

- Mondom, hogy elejtettem!!!

Az elejtettem szóalak két, egymással homonimikus viszonyban álló jelentést hordoz, amely a dialógus humoros hatását eredményezi: 1) megfog, elkap; 2) elveszít, leejt. Az elejt szótári homonimában mindemellett ellentétes jelentésmozzanatot is megfigyelhetünk. A humor forrásául ennek köszönhetően a grice-i módmaxima megsértése okozta forgatókönyvváltás szolgál. A megértésben itt is szerepet játszik a szöveg mögötti két sast ábrázoló kép.

${ }^{2} \mathrm{Az}$ ábra forrása: Hungaro-Mém Hungarizált Mémek Facebook-oldal: https://goo.gl/Nuq6eV [2017. március 27.] 


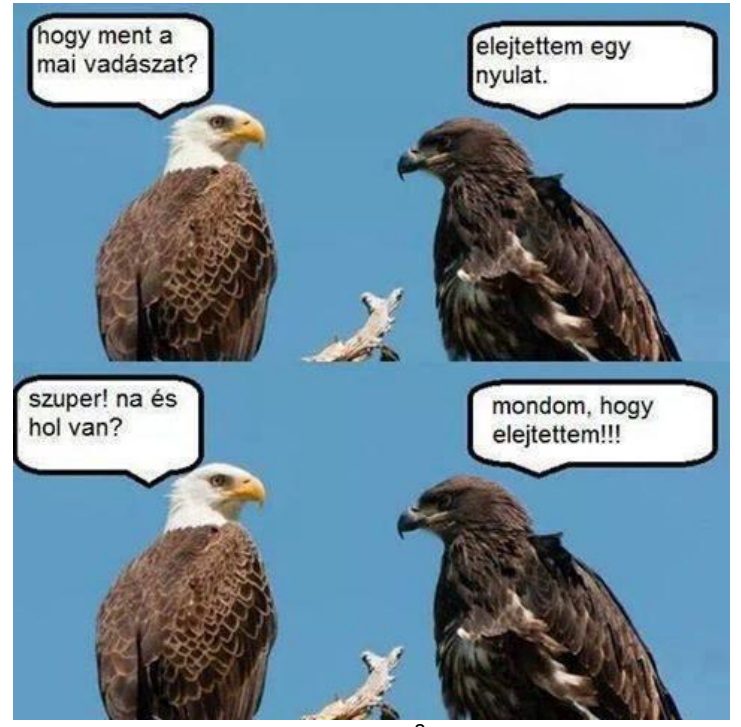

3. ábra ${ }^{3}$

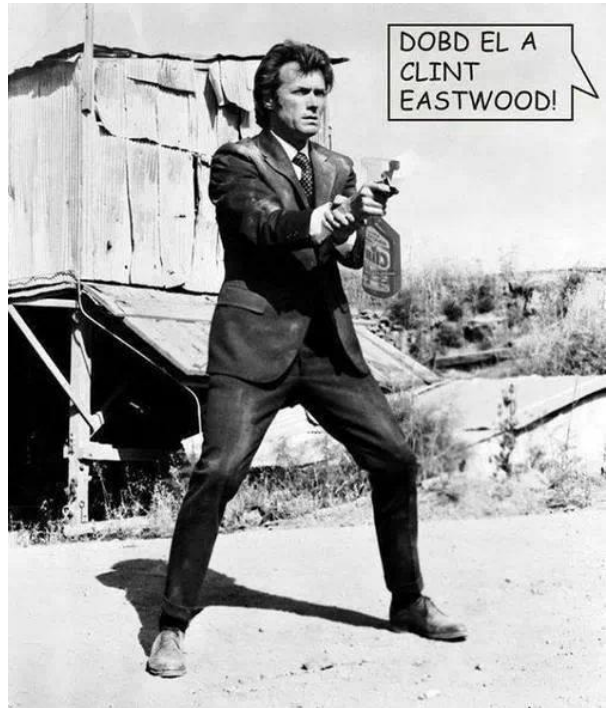

4. ábra ${ }^{4}$

${ }^{3} \mathrm{Az}$ ábra forrása: a Kék Duna Rádió Facebook-oldala: https://goo.gl/id8uh6 [2017. március 27.]

${ }^{4} \mathrm{Az}$ ábra forrása: Hungaro-Mém Hungarizált Mémek Facebook-oldal: https://goo.gl/Nuq6eV [2017. március 27.] 
A 4. ábra kép-szöveg együttesének dekódolásához szintén elengedhetetlen a vizuális elem. A képen Clint Eastwood, a legendás amerikai színész látható, kezében egy Clin márkájú tisztítószerrel. Az internetes mém ${ }^{5}$ Dobd el a Clint Eastwood! feliratának Clint szava a kézben lévő tisztítószernek köszönhetően két jelentést hordoz: 1) utal a színész keresztnevére, valamint 2) a tisztítószerre. Az azonos hangalak a szó második jelentésében a -t tárgyragnak köszönhetően jön létre, ennek következtében vegyes szerkezetű homonímiáról beszélhetünk (a fogalomról I. Lőrincz 2015: 61; Károly 1970: 81).

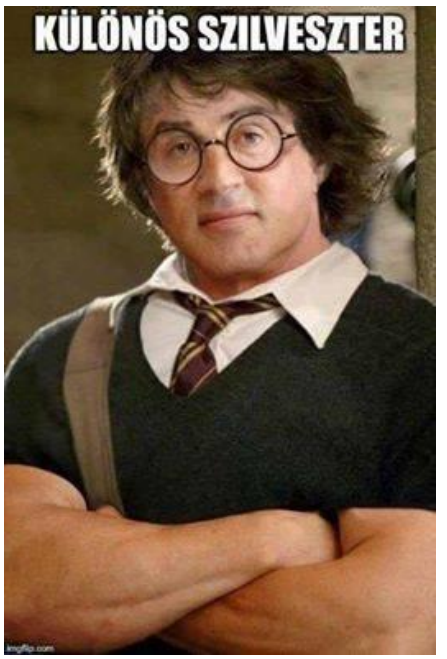

5. ábra ${ }^{6}$

A szöveg és a kép kölcsönhatását szemlélteti az 5. ábra is. A képen az amerikai színész, Sylvester Stallone látható Harry Potter-öltözetben. A Különös szilveszter képfelirat a vizuális elemnek köszönhetően több értelmezést is kap:

1) a szilveszter mint homofónia (a fogalomról I. Károly 1970: 81; Lőrincz 2015: 61) Sylvester Stallone-ra utal; különössé a ruházat teszi őt;

${ }^{5} \mathrm{Az}$ internetes mémek divatszerüen terjedő - többnyire - szöveg, kép vagy kép-szöveg kapcsolatok. Élettartamuk az egy-két héttől az évekig terjedő skálán mozog (Veszelszki 2013). Shifman a következőképp definiálja az internetes mémeket: A „digitális tartalmak olyan csoportja, amelyek tartalmilag, formailag és / vagy álláspontjukat tekintve közös jellegzetességekkel bírnak, létrehozójuk tisztában van más hasonló tartalmak létezésével, továbbá nagyszámú felhasználó az interneten terjeszti, utánozza és/vagy módosítja őket” (Shifman 2016). Horváth Dóra, Mitev Ariel és Veszelszki Ágnes tanulmányukban (Horváth-Mitev-Veszelszki 2013) nyolc mémfaktort jegyeznek le: egyediség, felismerhetőség, aktualitás, variálhatóság, azonosulás, maszkszerüség, humor, szerethetőség.

${ }^{6}$ Az ábra forrása: a Kék Duna Rádió Facebook-oldala: https://goo.gl/id8uh6 [2017. március 27.] 
2) a szilveszter 'ünnep' jelentésben az év utolsó napjaként is értelmezhető, amely

3) a különös jelzőjével együtt pragmatikai, kulturális jelentéstöbbletet vesz fel, Cserháti Zsuzsa Különös szilveszter című dalát implikálja.

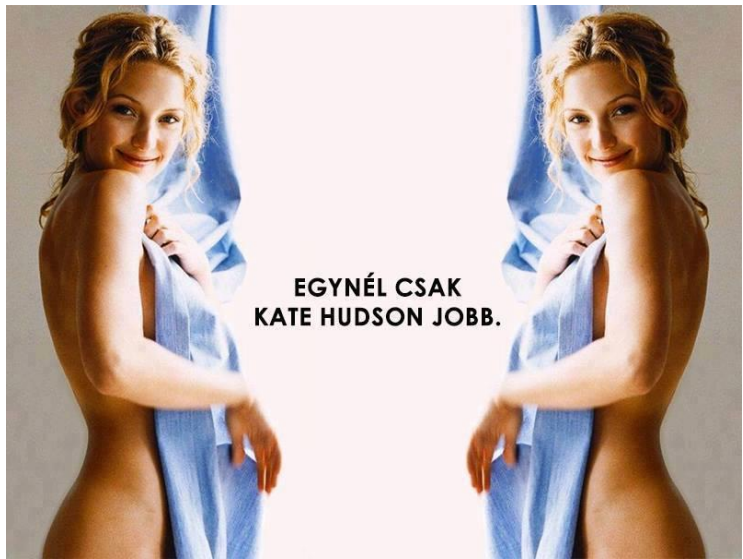

6. ábra ${ }^{7}$

Kiejtésbeli homonímia (a fogalomról I. Károly 1970: 81; Lőrincz 2015: 61) figyelhető meg a 6. ábrán látható internetes mém esetében is. A színésznő, Kate Hudson keresztneve két olvasatban jelenik meg: 1) egyrészt a Kate női névként; 2) másrészt pedig a kiejtésbeli hasonlóságra építve a két számnévként. $A$ mém humorát a kép és a szöveg összjátékának köszönhetően - az utóbbi értelmezés adja.

\section{2. Ékezethiányos írásmód eredményezte homonímia}

Az interneten való ékezethiányos írásnak több oka is lehet. Az ékezetek elhagyásának okát Bódi Zoltán a következőkben látja: „[...] a messengeren való beszélgetés gyorsasága vetekszik az élő párbeszéd gyorsaságával, így az embereknek egyszerüen nincsen idejük arra, hogy odafigyeljenek a kissé több figyelmet igénylő ékezetes karakterek alkalmazására. [...] Ahogyan felgyorsultak a világ történései, ugyanúgy az interneten is megfigyelhető egyfajta gyorsaságra való törekvés" (Bódi 2004: 29). A szavak szabálytalan írásmódján keresztül azonban saját személyiségünk is kifejeződhet, „a hálózat használói a maguk képére alakítják a nyelvet, külső kontroll nélkül”, így a helyesírási - mindemellett a grammatikai és nyelvhelyességi hibákat is - csak bizonyos megkötésekkel, fenntartásokkal tekinthetjük hibáknak (Bakonyi 1997). Az ékezethiányos írásmód az interneten olykor félreértésekhez is vezet (vö. Csányi 2001) és a humor forrásává válik.

${ }^{7} \mathrm{Az}$ ábra forrása: Hungaro-Mém Hungarizált Mémek Facebook-oldal: https://goo.gl/Nuq6eV [2017. március 27.] 


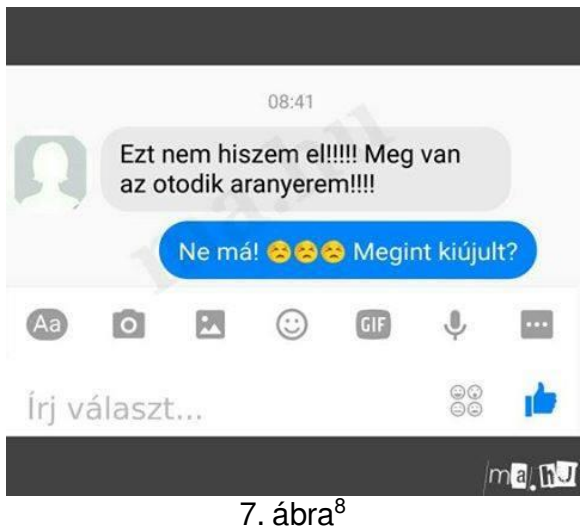
ábra):

Ezt bizonyítja többek között a 2016-os nyári olimpiához kötődő párbeszéd (7.

(2) - Ezt nem hiszem el!!!!! Meg van az otodik aranyerem!!!!

- Ne má! :( :( : (Megint kiújult?

A félreértést az aranyérem szó ékezetek nélküli írása okozza, melynek köszönhetően a díj jelentés mellett az aranyér mint betegség értelmezés jelenik meg. Az aranyerem ékezethiányos szóalak vegyes szerkezetü homonímiát hordoz: aranyérem - aranyer-em.

- Hogy van a repulo nemetul?

- Nem tudok nemetul.

- Es angolul?

- Angolul meg plane.

8. ábra ${ }^{9}$

A 8. ábrán látható párbeszédben a plane szóalak két lehetséges értelmezésének - 1) „még úgy sem”; 2) a repülőgép angolul - egymáshoz való homonimikus viszonya nyelvközi, a magyar és az angol nyelvi írott alaknak köszönhető. A magyar és angol szóalak egybeesését az ékezethiányos írásmód okozza.

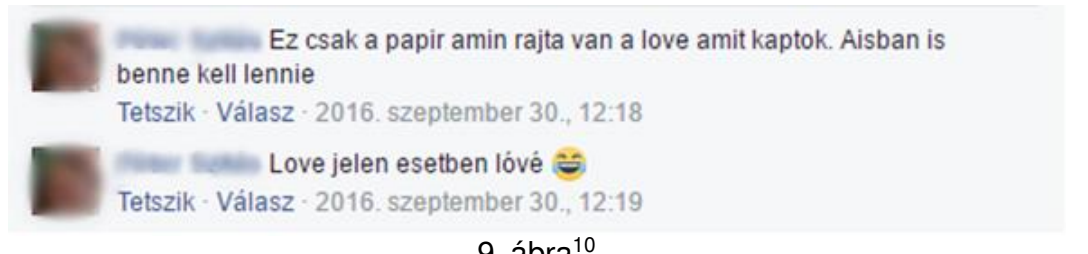

$$
\text { 9. ábra }{ }^{10}
$$

\footnotetext{
${ }^{8}$ Az ábra forrása: a Kék Duna Rádió Facebook-oldala: https://goo.gl/id8uh6 [2017. március 27.]

${ }^{9}$ Az ábra forrása: a Kék Duna Rádió Facebook-oldala: https://goo.gl/id8uh6 [2017. március 27.]

${ }^{10}$ Az ábra forrása: egy zárt Facebook-csoport [2017. március 27.]
} 
Hasonló nyelvközi homonimikus viszony alakul ki a love szóalakon belül is ( 9 . ábra). A vonatkozó megnyilatkozás a love szó angol és magyar kiejtésével egyaránt értelmes, a két jelentés azonban eltérő értelmezést ad a mondatnak:

(3) Ez csak a papír, amin rajta van a love (ejtsd láv - értsd szeretet), amit kaptok.

(4) Ez csak a papír, amin rajta van a lóvé (szleng pénz), amit kaptok.

Csányi János 2001-es gyűjtésében (Csányi 2001: 44-46) is találhatunk az aranyeremhez hasonló, nyelven belüli homonímiát mutató példákat:

(5) Szegenyes lakas volt, ezért meglepodtem, amikor lattam, hogy a szobaban ott all egy nagy teve.

(6) Megnyugodva vezettem, mert az ut szeles volt.

(7) A fegyor a fegyenc megszokese utan: „Hat ez bizony meglepett.”

(8) Nem azt kerdeztem, hogy milyen szinu az orrod, hanem azt, hogy miert veres.

(9) Csengetett, hogy leolvassa a fogyasztasomat, de nagyon rosszkor jott a gazember.

A felsorakoztatott példák humorának forrása a félreérthetőség, a kétértelműség, a kifejezés homályossága. Paul Grice társalgási maximái felől nézve a mód maximájának - Légy érthetó! Kerüld a kifejezés homályosságát! Kerüld a kétértelmúséget! - megsértése figyelhető meg (Grice 1975: 41-57; magyarul 1997: 213-227).

\subsection{Kvázi-poliszémikus szimbólumjáték}

A marketing, a reklám világában és a digitális kommunikációban is egyre több példát találhatunk az egy-egy szóalakon belüli kiemelés különböző formáira (pl. nagybetűs kiemelés, kiemelés színekkel, szimbólumokkal).

A 10. ábrán látható képmontázs feliratában az alábbi szókapcsolat olvasható: vasárnapi SiÉszTA. A nagybetűs kiemelésnek köszönhetően a SiÉszTA szóalak olvasatai: 1) szieszta; 2) séta. A szieszta mint tevékenység, illetve a séta mint a pihenés, a szieszta egyik formája (hiponimája; a fogalomról I. Kiefer 2007: 28) szemantikailag metonimikus összefüggést mutatnak (vö. Károly 1970: 369-371), ezáltal a SiÉszTA szóalak poliszemantikus jelentésűvé válik. A jelentésváltozás szempontjából jelentéssürítés figyelhető meg, így a nagybetűs kiemelés célja egyszerre lehet a többértelműség elérése és a nyelvi gazdaságosságra való törekvés is. 


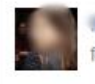

februair $12,10 \cdot 12$ - 4 .

.vasárnapi S I E' sz T A E

Nagy az öröm! Min. 100 fehér popót láttunk ma @ természetesen ŐZé volt mind...e
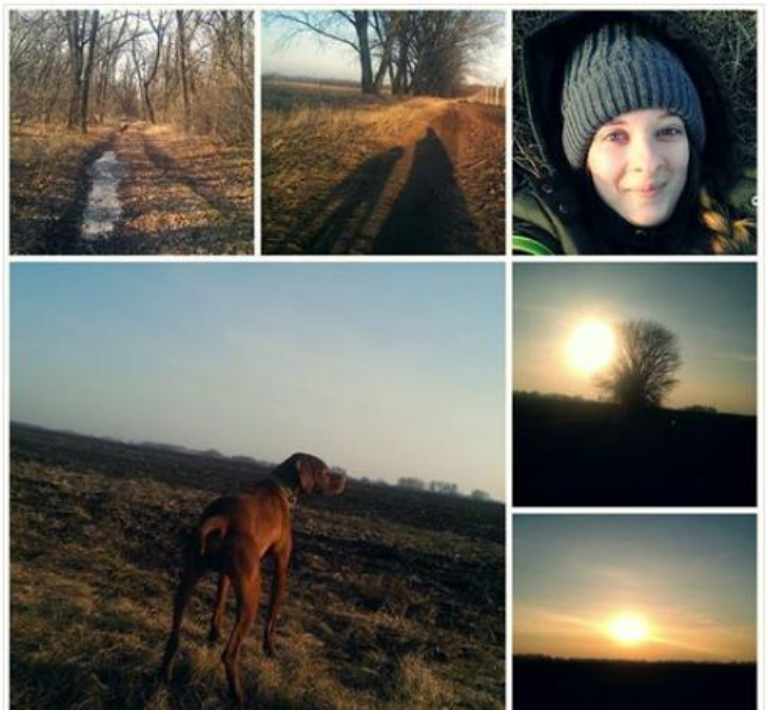

10. ábra ${ }^{11}$

Hasonlóképpen magyarázható a 11. ábra MADE IN SLOVENIA felirata is, ahol a love szórész zöld színnel való kiemelése két olvasatot eredményez: 1) made in Slovenia = 'Szlovéniában készült'; 2) made in love = 'szeretettel készítve'. A két olvasat egy szószerkezetben való előfordulása a jelentések szorosabb összekapcsolódását eredményezi: szeretettel készítve Szlovéniában.

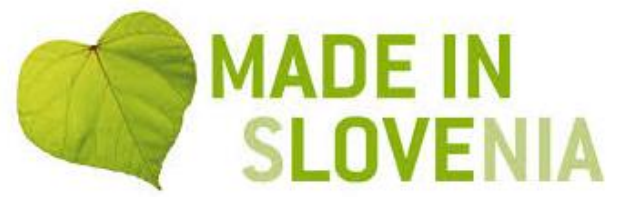

11. ábra ${ }^{12}$

${ }^{11}$ Az ábra forrása: egy Facebook-felhasználó üzenőfala [2017. március 27.]

${ }^{12}$ A példáért köszönet prof. dr. Alberti Gábornak, a PTE BTK Nyelvtudományi Tanszék tanárának a negyedik Újdonságok a szemantikai és pragmatikai kutatásokban c. konferencián megtartott előadásomhoz kapcsolt ötletként, javaslatként. Az ábra forrása: Matejfaganel.wordpress.com: https://goo.gl/XtyRD3 [2017. március 27.] 


\subsection{Homonimitás az akronimákban}

Az már megszokott, hogy nyelvünkben olykor több szónak is azonos a rövidítése (pl. Ui. = 'ugyanitt', 'utóirat'; ui. = 'ugyanis'). A rövidítések használata az internetes kommunikációban is egyre gyakoribb. Létrejöttüket nemcsak az írás sebességének a gyorsítása, hanem a játékösztön, a humor, a kreativitás kibontakoztatása is motiválhatja. Ezt bizonyítják az alábbi, a futballt kedvelők internetes kommunikációjában használt példák is, amelyekben a szóalakok jelentései között homonimikus viszony fedezhető fel.

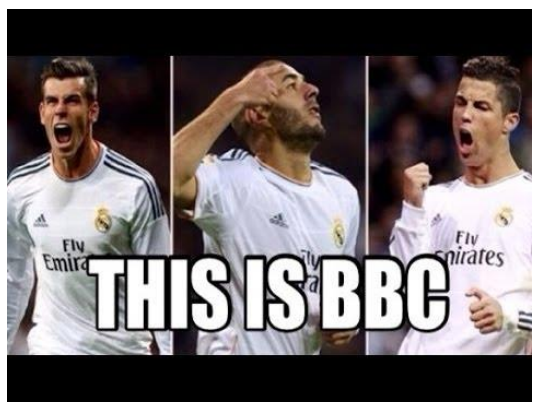

12. ábra ${ }^{13}$

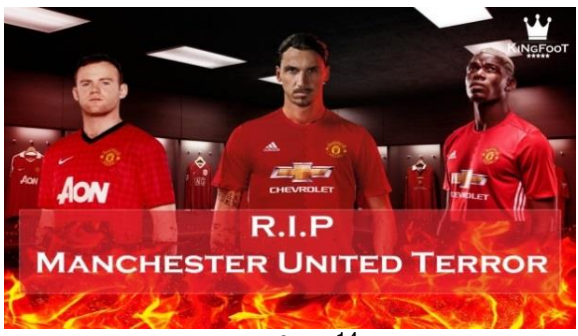

13. ábra ${ }^{14}$

(10) $B B C^{1}=$ brit közszolgálati müsorszolgáltató

$B B C^{2}$ = a Real Madrid futballcsapat támadóinak nevéből alkotott betűszó:

(Karim) Benzema, (Gareth) Bale, Cristiano (Ronaldo) (12. ábra)

$R I P^{1}=$ ang. rest in peace 'nyugodjon békében'

$R I P^{2}$ = a Manchester United játékosainak nevéből alkotott betűszó: (Wayne Mark) Rooney, ${ }^{15}$ (Zlatan) Ibrahimovic, (Paul) Pogba (13. ábra) ${ }^{16}$

${ }^{13}$ Az ábra forrása: Pinterest: https://goo.gl/rNbq9u [2017. december 6.]

${ }^{14} \mathrm{Az}$ ábra forrása: Youtube: https://i.ytimg.com/vi/iJgX3WX6yFM/maxresdefault.jpg [2017. december 6.]

${ }^{15}$ Wayne Mark Rooney 2017 nyarán a Manchester Unitedtől az Evertonhoz igazolt.

${ }^{16} \mathrm{Az}$ ábrán látható Manchester United Terror feliratnak köszönhetően a $R I P^{1}$ és $R I P^{2}$ jelentései között ok-okozati összefüggés is létrejön. A játékosság motiválta felirat azt sugallja, hogy a három futballista az összjátékuknak köszönhetően „rettegésben tartja” az ellenfelet. 
$M S N^{1}$ = egykori azonnali üzenetküldő szolgáltatás (Windows Live Messenger) $M S N^{2}$ = a Barcelona futballcsapat csatárainak nevéből alkotott betűszó: (Lionel) Messi, (Luis Alberto) Suárez, Neymar ${ }^{17}$ (da Silva Santos Júnior)

(13) $P H D^{1}=$ tudományos fokozat

$P H D^{2}$ = a Chelsea futballcsapat támadóinak nevéből alkotott betűszó: Pedro (Rodríguez Ledesma), (Eden Michael) Hazard, Diego (Costa)

\section{A lexikális jelentésviszonyok témaköre a szlovákiai magyar anyanyelvtankönyvekben}

A hangalak és a jelentés kapcsolata szerinti jelentéstipológia az anyanyelvoktatás egyik központi témaköre. A kisdiákok már a 2. osztályban megismerkednek az egyés többjelentésű, a rokon értelmű, az azonos alakú, valamint az ellentétes jelentésű szavakkal. Az itt tanultak később kibővülnek az általános iskola felső tagozatán és a középiskolában. A szlovákiai magyar anyanyelvoktatásban az 5 . osztályos tankönyv (I. Bukorné-Bolgár 2009) tananyag és gyakorlatok szintjén részletezi újból a 2. osztályban tanultakat. A 9. osztályos tankönyvben (l. Bolgár-Bukorné 2012) a felső tagozatos (5-9. osztály) ismeretanyag összefoglalójaként szolgáló év végi ismétlő fejezetben kerülnek újra tárgyalásra. Az elsajátított ismeretek később a középiskola 3. osztályában (I. Uzonyi Kiss-Csicsay 2012) bővülnek ki a hasonló hangzású szavak témakörével. A tankönyvek gyakorlatai a szókincsbővítésre, a szótárhasználatra, az egyes típusok szövegbeli beazonosítására fókuszálnak, amelyek összhangban vannak az ŠVP (Štátny vzdelávací program; magyarul: Állami Művelődési Program) magyar nyelv és irodalom tantervével (lásd az ISCED 2 és ISCED 3 mellékleteit: W1, W2, W3, W4), valamint könnyed, kreatív feladatként pedig olyan vicceket kell keresniük vagy írniuk a diákoknak, melyekben a humor forrását egy-egy szó, szókapcsolat jelentésváltozása, lexikális jelentésviszonya eredményezi. Egy-egy jelentésviszonyt kiemelő feladat azonban folyamatosan megjelenik más témakörök tárgyalásán belül is, például a magán- és mássalhangzóknál vagy a szófajtannál (főleg a mellékneveknél).

\section{Javaslatok a lexikális jelentésviszonyok tanításának újszerü megközelítéséhez}

Mivel a diákok idejük nagy részét az interneten, digitális környezetben töltik, a tárgyalt multimediális szövegek beépítése az oktatási folyamatba az otthon és az iskola közötti „szakadék” csökkentését jelenthetné. ${ }^{18} \mathrm{~A}$ tanulmányban vizsgált internetes mémek és egyéb kép-szöveg együttesek egyrészt illusztrációkként szerepelhetnének az anyanyelvtankönyvek vonatkozó fejezeteinek elméleti tananyagaiban, vagy csupán segédeszközként (nyomtatva papíron, kivetítve stb.) a tanórán,

\footnotetext{
${ }^{17}$ Neymar da Silva Santos Júnior 2017 nyarán a Barcelonától a francia Paris SaintGermainhez igazolt.

${ }^{18}$ A tanulmányban ismertetett tananyag-kiegészítő javaslatok a 11-18(19) éves korosztályt, az általános iskola felső tagozatának és a középiskolák diákjait célozzák meg.
} 
másrészt gyakorlatok, feladatok szerves részét képezhetnék (ez utóbbira alább szintén teszek javaslatot). Figyelemfelkeltő szövegdobozokként bekerülhet a tankönyvekbe, illetve érdekességként elhangozhat a tanórán, hogy a főként digitális kommunikációban elterjedt ékezethiányos írásmód is eredményezhet homonímiát, azon belül is - az írásbeli azonosságnak köszönhetően - homográfiát (pl. A teve a sivatag hajoja. Szegenyes lakas volt, ezért meglepodtem, amikor lattam, hogy a szobaban ott all egy nagy teve.; vö. 3.2. fejezet). Olykor a mozaikszavak is hordozhatnak homonimikus jelentésviszonyt, illetve a homonímiát kihasználva tudatosan hoznak létre a nyelvhasználók szókapcsolatokból, személynevek egymás mellé rendeléséből mozaikszavakat (I. sportnyelvi példák: pl. BBC, $M S N$; vö. 3.4. fejezet). Az egy-egy szóalakon belüli szimbólumhasználatnak vagy nagybetűs kiemelésnek köszönhetően pedig többletjelentést vesz fel a kifejezés; egyfajta poliszémikus viszony alakul ki a szóalakból kiolvasható szavak között, amelyek így a kiinduló szóalak jelentéseit adják (pl. SiÉszTA = séta + szieszta; vö. 3.3. fejezet). A 3.1. fejezetben elemzett kép-szöveg együttes típusok főként az általános iskola 5. osztályának tananyag-kiegészítéseként szolgálhatnak a poliszemantikus és homonimikus viszonyok ismertetésekor, míg a további fejezetek példaanyaga a már jelentéstani alapismeretekkel rendelkező középiskolások nyelvről való kritikai gondolkodását segíti elő.

A feladatjavaslatokat illetően négy gyakorlatot ismertetek, amelyek példaanyaga az internet nyelvhasználatára reflektálva segíti a tanulókat a jelentésviszonyok megértésében:

1. a) Milyen jelentéseket párosíthatunk az alábbi ékezethiányos szavakhoz? Variáljatok az ékezetekkel!

b) Poliszémiáról vagy homonímiáról beszélhetünk? Vitassátok meg! love, diszno, megorul, aranyerem

2. Hogyan változik a jelentés az alábbi internetes mémekben? Mi a humor forrása? ${ }^{19}$

${ }^{19}$ A Dobd el a Clint Eastwood! feliratú mém elemzése helyesírási kérdések (ti. vesszőhiány a megszólitás előtt) tárgyalására is lehetőséget ad.

A feladathoz felhasznált 1. kép forrása: Hungaro-Mém Hungarizált Mémek Facebook-oldal: https://goo.gl/Nuq6eV [2017. március 27.] 


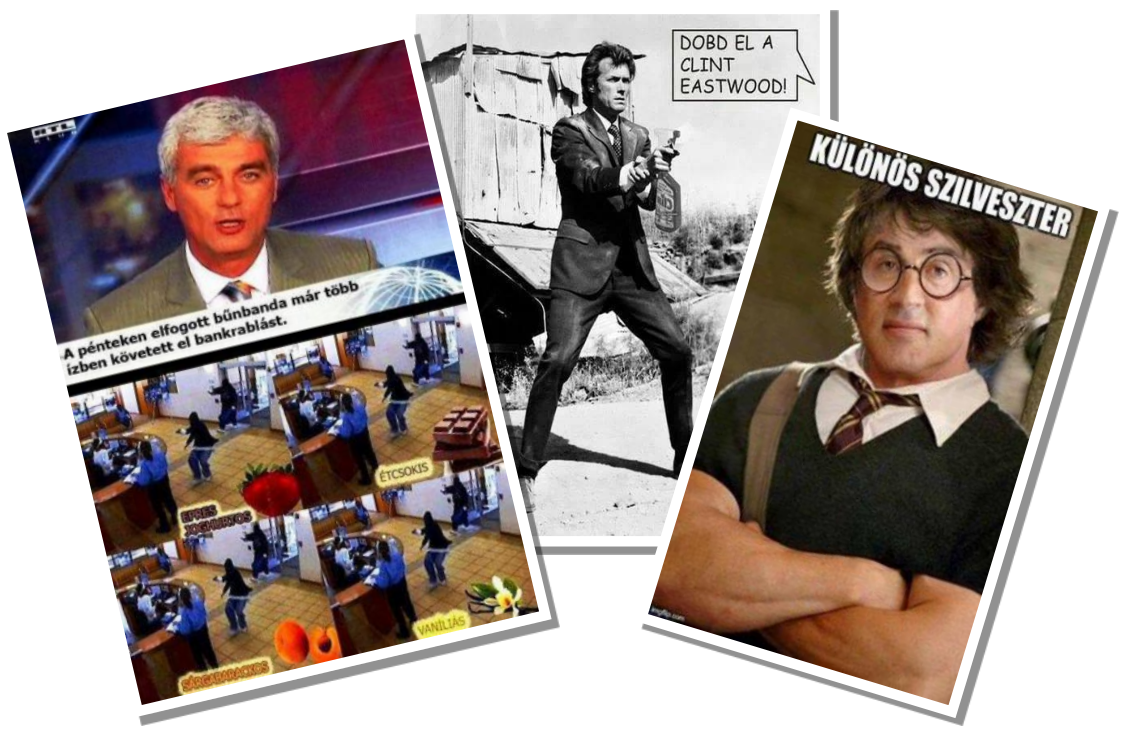

3. Gyűjtsetek/Írjatok olyan szavakat, amelyek ékezethiányos írásmódjuknak köszönhetően több jelentést is hordoznak!

A szóalakok közötti jelentésváltozás(ok)ra és a humor forrására mutassatok rá mémek készítésével!

4. Szmájlikat (azaz mosolyjeleket vagy emotikonokat) gyakran használunk e-mailjeinkben, SMS-einkben. Keress az alábbi emotikonokhoz minél több és változatosabb szinonimát! ${ }^{20}$

$:)$
$:($
$: S$
$: D$
$:^{*}$
$: P$
$;)$

A hangulatjelek szintén értelmezhetők kép-szöveg kapcsolatokként: a képi megjelenítéshez egy írásjelekből álló kód tartozik (I. 14. ábra). A negyedikként ismertetett feladatban a hangulatjelek szolgálnak példaként a szinonímia tárgyalásához. Bár a tanulmányomban a szinonímiával nem foglalkozom, a multimediális szövegek tekintetében úgy vélem, hogy helye van a feladatok sorában. A feladat válaszaiként megjelenő kifejezéseken keresztül rámutathatunk a szinonimák

${ }^{20}$ A feladat Szilágyi Barnabásnak, Veszelszki Ágnes egyik hallgatójának munkája. Forrás: http://www.veszelszki.hu/emotikonok-es-verbalis-informacio-szilagyi-barnabas.html [letöltve: 2017. 05. 13.] 
egymással való felcserélhetőségére és fel nem cserélhetőségére is (vö. Károly 1970: 81).

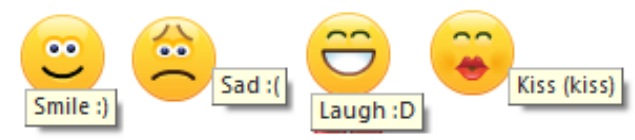

14. ábra. A Skype csevegőprogram hangulatjelei

\section{6. Összegzés}

Tanulmányomban a multimediális szövegeken keresztül - internetes mémek, képszöveg kapcsolatok - közelítem meg a lexikális jelentésviszonyok általános és középiskolai szintű tanítását. A tanulás-tanítás hatékonyságához hozzájáruló tényezők közül a vizualitásra és a humorra helyezem a hangsúlyt. A korpuszom válogatott példaanyaga a homonímiát és a poliszémiát emeli ki mint a humor eszközét. A Z és már az alfa generáció (az 1996-2010 között és a 2010 után születettek) mindennapjainak is szerves részét képezi a digitális technológia használata, ezért a kép-szöveg kapcsolatok mint a digitális (internetes) kommunikáció szerves részét képező multimediális szövegek segédeszközként való felhasználása az oktatásban élményközpontúvá teheti a tanulást. A feladatok és az elméleti tananyagrészt kiegészítő javaslataim célja a diákok anyanyelvi ismeretek iránti motivációjának felkeltése. A mozaikszavakhoz, valamint az ékezethiányos írásmódú kifejezésekhez társuló homonimitás, a szimbólum-, illetve a nagybetűs kiemelés eredményezte poliszémia a mai magyar nyelvben megjelenő változásoknak egy szeletét mutatja. Az ékezethiányos szavakban és az internetes mémekben való jelentéseket kereső feladatok hozzájárulnak ahhoz, hogy rámutathassunk és tudatosíthassuk a diákokkal a nyelv folyamatos változását és a szókészletbeli mozgást. A mémgyüjtésre és -készítésre felhívó harmadik feladat pedig a kognitív kompetenciák mellett a kreativitást is fejleszti.

\section{Hivatkozások}

Attardo, Salvatore 1994. Linguistic Theories of Humor. Berlin: Walter de Gruyter.

Bakonyi Géza 1997. A hálózat használata a nyelv- és irodalomtudomány területén. (NIIF Információs Füzetek) Budapest: NIIF. http://mek.niif.hu/01200/01280/html/1.12.06/ [2017. 04. 8.].

Balázs Géza 2005. Az internetkorszak kommunikációja. In Balázs Géza - Bódi Zoltán (szerk.) Az internetkorszak kommunikációja. Budapest: GondolatInfonia. 25-57.

Bódi Zoltán 2004. A szóbeliség kifejeződése az internetes kommunikációban. Infonia IV/1:26-38.

Csányi János 2001. Az internetnyelv csalafintaságai. In Balázs Géza - Grétsy László (szerk.) Szójátékos anyanyelvünk. Válogatas a Nemzeti Kulturális Örökség Minisztériuma anyanyelvi pályázataiból. Budapest: Nemzeti Kulturális Örökség Minisztériuma. 44-46. 
Cseresnyési László 2009. Poliszémia és jelentéskiterjesztés. Az elveszett kontextus nyomában. Magyar Nyelvjárások XLVII:5-20.

Domonkosi Ágnes 2005. Az internet nyelvhasználatának empirikus kutatási lehetőségei. In Balázs Géza - Bódi Zoltán (szerk.) Az internetkorszak kommunikációja. Budapest: Gondolat-Infonia. 143-158.

Fegyverneki Gergő 2014. Digitális alapú motiváció - jó gyakorlatok a magyaróráról. Oktatás-Informatika VI/1:70-80.

Grétsy László 2000. Nyelvi kreativitás, játékosság az anyanyelvi órán. Magyartanítás 41/5:17-23.

Grice, H. Paul 1975. Logic and conversation. In Peter Cole - Jerry L. Morgan (szerk.) Syntax and Semantics Vol. 3. Speech Acts. New York: Academic Press. 41-58.

Grice, H. Paul 1997. A társalgás logikája. In Pléh Csaba - Síklaki István Terestyéni Tamás (szerk.) Nyelv, kommunikáció, cselekvés. Budapest: Osiris Kiadó. 213-227.

Hegedűs Gábor 2010. A játékpedagógia elmélete és gyakorlata a konstruálásban. Weboldal. MásKép(p) Tudományos. https://goo.gl/w8iN5m [2017. március 25.].

Horváth Dóra - Mitev Ariel - Veszelszki Ágnes 2013. Egy kiállítás mémei: a mémek megosztásának és interpretálásának fogyasztói élményvilága. In Király Éva (szerk.) „Kiterjesztett” marketing. Budapest: Budapesti Gazdasági Főiskola. 140-164.

Jakab György 2011. Írás és olvasás a digitális kultúrában. Új Pedagógiai Szemle 2011/10:92-98.

Jellinek Sára 2015. Humor és metafora a nyelvfilozófiában. In Bárány Tibor Zvolenszky Zsófia - Tőzsér János (szerk.) Metafora, relevancia, jelentés. (Pragmatika 3) Budapest: Loisir Kiadó. 173-190.

Károly Sándor 1970. Általános és magyar jelentéstan. Budapest: Akadémiai Kiadó. Kiefer Ferenc 2007. Jelentéselmélet. Budapest: Corvina.

Lőrincz Gábor 2011. A jelentéstan helyzete a szlovákiai magyar alapiskolákban. In Nagy Melinda (szerk.) A tudomány és az oktatás a tudásközpontú társadalom szolgálatában. A Selye János Egyetem III. Nemzetközi Tudományos Konferenciájának konferenciakötete. Komárom: Selye János Egyetem. 118-132.

Lőrincz Julianna 2015. Jelentéstani alapismeretek. Komárom: Szakképző és Felnőttképzési Intézet.

Manuel, Kate 2002. Teaching information literacy to generation Y. Journal of Library Administration 36/1-2:195-217. doi:10.1300/J111v36n01_12.

Nemesi Attila László 2015. Melyik pragmatikaelméletnek van a legjobb „humorérzéke”? In Bódog Alexa - Csatár Péter - Németh T. Enikő (szerk.) Használat és hatás. Újabb eredmények a magyarországi pragmatikai kutatásokban. Budapest: Loisir Könyvkiadó. 123-156.

Nyíri Kristóf 2011. Kép és idő. Budapest: Magyar Mercurius.

Pais Ella Regina 2013. Alapvetések a Z generáció tudománykommunikációjához tanulmány. Kézirat. Pécs: Pécsi Tudományegyetem. http://www.zgeneracio.hu/getDocument/1391. [2017.december 7.]

Patakfalvi Attiláné 2009. Játék szerepe a gyermek fejlődésében. In Frank Gabriella (szerk.) A Pedagógiai Intézet és Helytörténeti Gyüjtemény munkatársainak írásai. Budapest: Pedagógiai Intézet és Helytörténeti Gyűjtemény. 1-10. 
Pethő József 2006. Jelentéstan. Tankönyv a BA-képzés számára. Nyíregyháza: Nyíregyházi Főiskola.

Petőfi S. János 1996. Egy multimediális szövegek elemzésére alkalmas jelmodell néhány aspektusa. Jel-Kép 1996/2:87-95.

Prensky, Marc 2001. Digital natives, digital immigrants Part 2: Do they really think differently? On the Horizon 9/6:1-6. doi:10.1108/10748120110424843.

Raskin, Victor 1984. Semantic Mechanisms of Humor. Dordrecht: Reidel.

Renner, Vincent 2015. Lexical blending as wordplay. In Angelika Zirker - Esme Winter-Froemel (szerk.) Wordplay and Metalinguistic / Metadiscursive Reflection. Authors, Contexts, Techniques, and Meta-Reflection. Berlin, Boston: De Gruyter. 119-134. doi:10.1515/9783110406719-006.

Schirm Anita 2013. A humor szerepe a nyelvészet oktatásában. In Vargha Katalin T. Litovkina Anna - Barta Zsuzsanna (szerk.) Sokszínú humor. A III. Magyar Interdiszciplináris Humorkonferencia előadásai. (Segédkönyvek a nyelvészet tanulmányozásához 151) Budapest: Tinta Könyvkiadó, ELTE Bölcsészettudományi Kar, Magyar Szemiotikai Társaság. 50-58.

Séra László 2008. Humor a tanulásban. In Daczi Margit - T. Litovkina Anna - Barta Péter (szerk.) Ezerarcú humor. Az 1. Magyar Interdiszciplináris Humorkonferencia elöadásai. (Segédkönyvek a nyelvészet tanulmányozásához 79) Budapest: Tinta Könyvkiadó. 264-272.

Shifman Limor 2016. Az internetes mémek definiálása. Fordította Pölcz Róbert. Apertúra 2016/ősz.

Szekszárdi Júlia 2015. Hogyan szerettessük meg az olvasást? Weboldal. Modern Iskola. http://moderniskola.hu/2015/06/hogyan-szerettessuk-meg-az-olvasast/ [2017. március 22.].

Szikszainé Nagy Irma 1999. Leíró magyar szövegtan. Budapest: Osiris Kiadó.

Veszelszki Ágnes 2012. Új írásjelek digitális és kézzel írt szövegekben. Anyanyelvpedagógia 2012/4.

Veszelszki Ágnes 2013. Humor a digitális kommunikációban: az internetes mémek. In Vargha Katalin - T. Litovkina Anna - Barta Zsuzsanna (szerk.) Sokszínú humor. A III. Magyar Interdiszciplináris Humorkonferencia előadásai. (Segédkönyvek a nyelvészet tanulmányozásához 151) Budapest: Tinta Könyvkiadó, ELTE Bölcsészettudományi Kar, Magyar Szemiotikai Társaság. 11-25.

\section{Hivatkozott tankönyvek, tantervek}

Bolgár Katalin - Bukorné Danis Erzsébet 2012. Magyar nyelv az alapiskola 9. osztálya és a nyolcosztályos gimnázium 4. osztálya számára. Bratislava: Slovenské pedagogické nakladatel'stvo - Mladé letá.

Bukorné Danis Erzsébet - Bolgár Katalin 2009. Magyar nyelv az alapiskola 5. osztálya számára. Bratislava: Slovenské pedagogické nakladatel'stvo Mladé letá.

Uzonyi Kiss Judit - Csicsay Károly 2012. Magyar nyelv. Tankönyv a gimnáziumok és a szakközépiskolák 3. osztálya számára. Bratislava: TERRA vydavatel'stvo. 
W1 = Štátny vzdelávací program. Mad’arský jazyk a literatúra. Príloha ISCED 2. http://www.statpedu.sk/files/articles/dokumenty/statny-vzdelavaciprogram/madarsky_jazyk_literatura_isced2.pdf [2017. november 14]

W2 = Štátny vzdelávací program. Mad'arský jazyk a literatúra. Príloha ISCED $3 A$. http://www.statpedu.sk/files/articles/dokumenty/statny-vzdelavaciprogram/madarsky_jazyk_literatura_isced3a_titul.pdf [2017. november 14]

W3 = Vzdelávací štandard $z$ mad'arského jazyka a literatúry pre nižšie stredné vzdelávanie. http://www.statpedu.sk/files/articles/dokumenty/inovovanystatny-vzdelavaci-program/mjl_nsv_2014.pdf [2017.november 14]

W4 = Vzdelávací štandard učebného predmetu mad'arský jazyk a literatúra pre gymnáziá so štvorročným vzdelávacím programom. http://www.statpedu.sk/files/articles/dokumenty/inovovany-statny-vzdelavaciprogram/madarsky_jazyk_a_literatura_g_4_r.pdf [2017.november 14]

\section{A szerzőről}

Szerdi llona Királyhelmecen született 1989 májusában. 2012-ben magyar nyelv és irodalom - német nyelv és irodalom szakon tanári oklevelet szerzett a Selye János Egyetem Tanárképző Karán. Jelenleg az egyetemen müködő Magyar Nyelv és Irodalom Doktori Iskola hallgatója. Kutatási területe a netnyelvészet, azon belül az internetes nyelvhasználat felhasználásának lehetőségei az anyanyelvi oktatásban. Elérhetősége:szerdi.ilona@gmail.com 